\title{
Training and Assistance Classroom Action Research (CAR) for Teacher MA Manbaul Bayan Lombok Timur
}

\author{
A. Doyan ${ }^{1 *}$, Susilawati ${ }^{1}$, M. Zuhdi ${ }^{1}$, H. Sahidu ${ }^{1}$ \\ ${ }^{\text {I} P h y s i c s ~ E d u c a t i o n, ~ T e a c h e r ~ a n d ~ E d u c a t i o n ~ F a c u l t y, ~ M a t a r a m ~ U n i v e r s i t y, ~ M a t a r a m, ~ W e s t ~ N u s a ~ T e n g g a r a, ~ I n d o n e s i a ~}$
}

\author{
*Corresponding Author: A. \\ Doyan, Physics Education, \\ Mataram University, Mataram, \\ West Nusa Tenggara, \\ Indonesia. \\ Email: \\ aris_doyan@unram.ac.id
}

\begin{abstract}
This community service aims to provide insight into the knowledge of writing scientific papers in an effort to improve teacher professionalism. Training The methods used in community service activities are the lecture, discussion and question, and answer method. Results of community service activities overall it can be considered quite good, seen from the presence of trainees reaching $90 \%$ of the number of MA Manbaul Bayan East Lombok teachers. The implementation procedure in the classroom action research training was rated as well based on positive responses from the participants and the level of mastery of the participants reached $75 \%$ of all stages of the implementation of the Classroom Action Research.
\end{abstract}

Keywords: Classroom Action Research, Training and Assistance

\section{Introduction}

Classroom action research is an effort that must be done by the teacher in solving problems in the classroom when learning takes place (Soesatyo, 2018). The success rate of learning is largely determined by the ability of teachers to manage to learn. The success of learning can be measured from the process carried out in learning and learning outcomes (Sanjaya et al, 2011).

Learning activities are basically routines that are carried out repeatedly every day, but there are so many problems faced by the teacher, both the problems of the learning process outside the classroom and problems in the classroom (Efron \& Rafid, 2019). The problems, especially in the learning process, are problems that must be handled by a teacher so that these problems can be overcome.

Teacher efforts in solving problems have often been done. Various attempts were made by the teacher in solving these problems, but the same problem often repeated again. The number of problems that exist, requires the teacher to prepare a variety of solutions in accordance with the problems faced (Suastra \& Ristiati, 2016).
That the same problems that have been resolved do not recur, then as a teacher must trace the problems that underlie these problems by conducting research or research commonly called classroom action research (Noorjannah, 2014). Facts that occur in schools are still lack of teacher's desire to conduct research, this can be known from the low scientific publications held by teachers (Aina et al, 2015).

Classroom action research is a concrete first step that starts from a very basic stage, namely analyzing problems that occur factually in the surrounding environment. Problems that exist in the classroom are varied problems. Subject teachers with other subject teachers have different problems, even in the same class. So the problem solving done is certainly not the same.

In order for the motivation and desire of the teacher to conduct research in solving problems, training and guidance are needed by competent lecturers in conducting research. So that it can encourage the desire of MA Manbaul Bayan East Lombok teachers to solve research-based classroom action problems. 


\section{Method}

The method of implementing training and guidance is carried out through the preparation stage, the implementation stage, and the evaluation stage (Doyan et al, 2018). The target of PTK training refers to an analysis of the situation of the programs agreed upon with MA Manbaul Bayan East Lombok teachers to improve teacher professionalism (Zulfadli \& Ferryansyah, 2017).

Table 1 Methods of Implementing Training and Devotion to Classroom Action Research

\begin{tabular}{|c|c|}
\hline Achievement Target & Method \\
\hline $\begin{array}{l}\text { Competency improvement } \\
\text { and } \\
\text { Understanding teacher of } \\
\text { MA Manbaul Bayan East } \\
\text { Lombok to } \\
\text { Classroom } \\
\text { Research. Action }\end{array}$ & $\begin{array}{l}\text { Workshop in the form of } \\
\text { discussion and lecture }\end{array}$ \\
\hline $\begin{array}{l}\text { Mastery of concepts, } \\
\text { objectives, benefits, and } \\
\text { stages of preparation of } \\
\text { scientific papers }\end{array}$ & $\begin{array}{l}\text { Lecture, question, and } \\
\text { answer, demonstration }\end{array}$ \\
\hline $\begin{array}{l}\text { Concept, Purpose, } \\
\text { Benefits and Stages }\end{array}$ & $\begin{array}{l}\text { Lecture, question and } \\
\text { answer, demonstration }\end{array}$ \\
\hline $\begin{array}{l}\text { Classroom Action } \\
\text { Research } \\
(\mathrm{CAR})\end{array}$ & \\
\hline $\begin{array}{l}\text { Form a group Professional } \\
\text { Teacher's Work in the } \\
\text { Application of Classroom } \\
\text { Action Research (CAR) }\end{array}$ & $\begin{array}{l}\text { Assistance in discussion } \\
\text { and lecture }\end{array}$ \\
\hline $\begin{array}{l}\text { Dissemination, Monitoring } \\
\text { and } \\
\text { Evaluation }\end{array}$ & $\begin{array}{l}\text { Lecture, } \\
\text { answer }\end{array}$ \\
\hline
\end{tabular}

Training activities and guidance for writing scientific papers in the form of classroom action research conducted at MA Manbaul Bayan, East Lombok. The Olympic guidance participants were attended by all MA Manbaul Bayan teachers. Underlying this activity is the lack of understanding and knowledge of teachers about classroom action research so that some teachers have difficulty writing their work. The outputs of this activity are products and services in the form of Handouts and improvement of the concept of classroom action research (CAR), as well as a collection of CAR reports and articles.

This community service activity began with the presentation of the concepts and stages of the preparation of a class action based research paper (CAR) by 4 instructors. The results of the identification of teacher understanding of the implementation of CAR is almost $75 \%$ of teachers do not fully understand CAR.

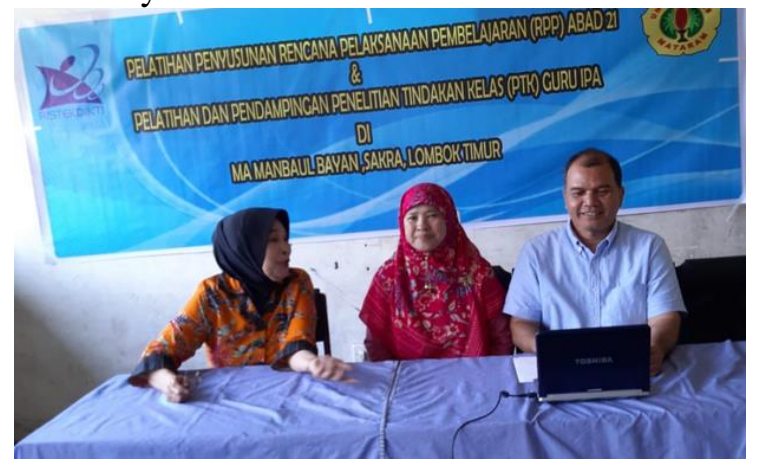

Figure 1. The instructor explains the concepts and stages of CAR implementation

Assistance is carried out by the instructor at the beginning of cycle 1 and at the end of each cycle, with a total of 2 cycles.

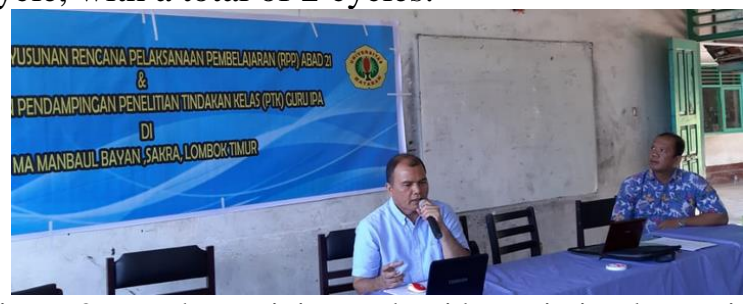

Figure 2. Teacher training and guidance in implementing the CAR cycle 1 .

The results of the scientific writing training for MA Manbaul Bayan East Lombok teachers can be carried out well with the results 1) The Training Participants consisted of 13 teachers from various fields, 2) The training went well and was followed by the teacher with enthusiasm in terms of the level of teacher participation as much as $90 \%$. 3) The response of the MA Manbaul Bayan East Lombok teacher was positive and looked forward to similar training activities. 4) MA Manbaul Bayan East Lombok teachers have been able to conduct CAR.

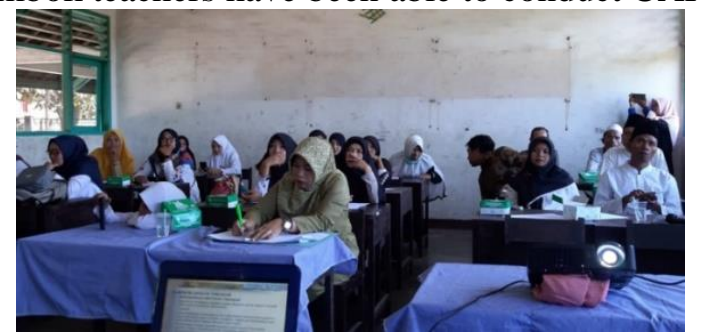

Figure 3 Teacher training and guidance in implementing the CAR evaluating.

This activity is carried out well but there are also inhibiting factors, including the time needed in activities is very limited. In addition, the busyness of the teachers to participate in various activities and the implementation of various tasks is 
quite difficult for instructors in mentoring the writing of CAR-based scientific papers.

\section{Conclusion}

CAR training and mentoring activities for MA Manbaul Bayan teachers are very useful for teachers in improving teacher professionalism. Teacher participation of trainees and guidance was very satisfying reaching $90 \%$. The level of mastery of teachers in conducting CAR reaches $75 \%$. So the teacher's response is positive and expects similar training activities to help improve teacher professionalism.

\section{Acknowledgment}

Thank you to the Chancellor of Mataram University for his staff who have funded this dedication activity to help improve the professionalism of teachers.

\section{References}

Y. Soesatyo, B. Suratman, W. T. Subroto, Harti, L. Hakim. (2018). Efektifitas Pemanfaatan Kemampuan Guru Ekonomi Kota Surabaya dalam Menulis Proposal Penelitian Tindakan Kelas. Jurnal Pemberdayaan Masyarakat Madani (JPMM), (2) 1. DOI: https://10.21009/JPMM.002.1.01.

Sanjaya, W. (2011). Penelitian Tindakan Kelas. Jakarta: Kencana.

S. E. Efron, R. Ravid. (2019). Action Research in Education, Second Edition: A Practical Guide. New York: The Guilford Press.

I. W. Suastra, N. P. Ristiati. (2016). Permasalahan Guru dalam Merancang dan Mengimplementasikan Penilaian Otentik dalam Pembelajaran Sains di SMP dan SMA. Seminar Nasional Riset Inovatif (Senari) ke-4. ISBN 978-602-6428-04-2.

Noorjannah,L. (2014). Pengembangan profesionalisme Guru Melalui Penulisan karya tulis ilmiah bagi guru profesional di SMA Negeri 1 Kauman Kabupaten Tulungagung I. Jurnal Humanity, 10 (1), 97-114.

Aina, M., Bambang, H.,Retni,S.S., Afreni, H.,\& Sadikin, A., (2015). Pelatihan Penulisan Karya ilmiah Bagi guruguru sma 8 kota jambi. Jurnal pengabdian pada masyarakat,30 (3).

A. Doyan, Susilawati, H. Soeprianto, S. Bahri. (2018). Pelatihan Olimpiade MIPA Bagi
Guru dan Peserta Didik SMA Kesuma Mataram. Jurnal Pengabdian Magister Pendidikan IPA 2018, (1) $1: 20$ - 23.

Zulfadli, Ferryansyah. (2017). Pelatihan Dan Bimbingan Pembuatan Karya Tulis Ilmiah Berbasis Penelitian Tindakan Kelas (PTK) di SD Muhammadiyah 1 Tarakan. Jurnal Pengabdian Masyarakat Borneo (1) 1 2017. 